\title{
Knowledge, attitude and practice of contraception among the postnatal women in a tertiary care hospital in a rural area in Southern Karnataka, India
}

\author{
Sasi Kripa*, Hana Shetty
}

Department of Obstetrics and Gynecology, Yenepoya Medical College, Deralakatte, Mangalore, Karnataka, India

Received: 27 March 2017

Accepted: 31 March 2017

*Correspondence:
Dr. Sasi Kripa,
E-mail: krips1988@gmail.com

Copyright: ( ) the author(s), publisher and licensee Medip Academy. This is an open-access article distributed under the terms of the Creative Commons Attribution Non-Commercial License, which permits unrestricted non-commercial use, distribution, and reproduction in any medium, provided the original work is properly cited.

\begin{abstract}
Background: Contraceptive advice is a component of preventive health care. It is necessary to stabilize the population and to conserve the natural resources for the future generations. An ideal contraceptive should suit an individual's personal, social, and medical characteristics and requirements. Socio-economic factors and education are few of the factors that play important roles in the acceptance of family planning.

Methods: A cross-sectional study regarding knowledge, attitude and practices of family planning was conducted in a tertiary care centre. The postnatal women were interviewed using a pretested, semi structured Performa during a fixed study period. The performa included details like socio demographic features, questions related to knowledge, attitude and practices (KAP) regarding contraceptive use.

Results: Results revealed poor good knowledge amongst females, but the knowledge was brought to practice in only $32 \%$ females mainly due to lack of knowledge and preference for male babies.

Conclusions: Family planning methods including male sterilization should be provided to all the couples and basic quality of education is to be raised.
\end{abstract}

Keywords: Attitude, Contraception, Family planning, Knowledge, Practice

\section{INTRODUCTION}

India is the pioneer country in the world to launch a nationwide family planning program in the year 1952, and during the third 5-year plan it was declared the very centre of planned development. In April 1976, the country framed its first national population policy which is now running under $\mathrm{RCH}$ (Reproductive and child Health) program, so that each and every couple in India is aware of the need for family planning. The need for contraceptive practices

lies is to control population explosion, to avoid unwanted births, to regulate intervals between pregnancies, to control the time at which births occur in relation to age of the parent. ${ }^{1}$
Family planning through contraceptive practices aims at achieving two main objectives; firstly, to have only the desired number of children and secondly, to have these children by proper spacing of pregnancies. ${ }^{2}$ A number of K.A.P. surveys have been carried out covering different population groups. ${ }^{3-6}$

Contraceptive advice is a component of preventive health care. It is necessary to stabilize the population and to conserve the natural resources for the future generations. An ideal contraceptive should suit an individual's personal, social, and medical characteristics and requirements. Socio-economic factors and education are few of the factors that play important roles in the acceptance of family planning. ${ }^{6}$ 
India's public sector programme claims to provide a cafeteria approach with a basket of choices. The methodmix in this programme includes five official methodsfemale sterilisation, male sterilisation, intrauterine contraceptive device (IUCD), oral contraceptives, and condoms. But modern spacing methods account for a very small fraction $(10 \%)$ of contraceptive use.

According to a study in Andhra Pradesh, out of 500 women, $96.8 \%$ were aware of contraception and with full knowledge of permanent contraception (both tubectomy and vasectomy) and $84.9 \%$ were aware of barrier methods. ${ }^{7,8}$ Their knowledge about IUCD and OCPs was only around $20 \%$. The source of knowledge is mostly through social circle.

According to National Family Health Survey, $56 \%$ of the married Indian women are using family planning. ${ }^{9}$ None of the females had complete basic knowledge regarding family planning methods. Also, television was their chief source of information. Reddy et al in 2003 stated that the major source of knowledge about Family Planning methods for the study population was magazines $(64 \%)$, followed by personal relations i.e. spouse, friends and relatives $(62 \%)$, mass media $(54 \%)$ and health personnel (34\%). ${ }^{8}$ In 2014, Kumari et al found that $96.8 \%$ were aware of one or more methods of contraception. But only $55 \%$ of women are using contraception methods. $30 \%$ expressed their concerns about the side effects as the reason for not using them. 55.5\% women are not using them due to lack of knowledge about their usage. Emphasis should be given on communication and good counselling women giving correct information about availability, source and the side effects of contraceptive methods. The major source of knowledge is social circle $(67.7 \%)$ and media $(18.18 \%)$. Similar results were found in another study $(42 \%)$ and $(15 \%)$ respectively. ${ }^{9}$ There are nearly 40 million women in India who would prefer to avoid becoming pregnant but are not practicing contraception.

\section{METHODS}

This study was conducted at Yenepoya Medical College Hospital This study was a hospital based cross-sectional study and was conducted in the postnatal ward in the Department of obstetrics and gynecology at Yenepoya Medical College Hospital over a period of 2 months (November to December 2016). All the women who delivered in the month of November 2016 (138 women) and December 2016 (142 women) were included in the study, total being 280 women. This study included all the women who delivered either vaginally or by LSCS. After taking an informed consent, women who fulfilled the inclusion criterion were interviewed by the postgraduate trainees.

The questionnaire elicited information regarding their age, educational status, number of children, knowledge and source of contraceptive methods, practicing of either male or female family planning methods. The attitude of females towards contraception was asked, while the attitude of husbands was assessed what their females perceived. To assess the knowledge, the methods were separately asked: pills, injectables, Intra-uterine Contraceptive devices (IUCDs), condoms, tubal ligation, vasectomy, Norplant and withdrawal method. The practice defines the usage of contraceptive methods by the either partners.

\section{Inclusion criteria}

- Married women within the reproductive age group living with their husbands.

\section{Exclusion criteria}

- Women with medical disorders.

\section{RESULTS}

About half of the women were between 20-30 years of age, that is $51 \%$ and 230 women out of 280 respondents were muslims by religion.

\section{Table 1: Age group.}

\begin{tabular}{|lll|}
\hline Age & Number & Percentage \\
\hline$<20$ yrs & 16 & 5 \\
\hline $20-30 y r s$ & 142 & 51 \\
\hline $30-40 y r s$ & 120 & 43 \\
\hline$>40 y r s$ & 2 & 1 \\
\hline
\end{tabular}

Table 2: Religion.

\begin{tabular}{|lll|}
\hline Religion & Number & Percentage \\
\hline Muslims & 230 & 82 \\
\hline Hindus & 42 & 15 \\
\hline Others & 8 & 3 \\
\hline
\end{tabular}

$90 \%$ of the respondents were housewives. The majority of the women had completed their primary education and 8 women were completely illiterate and only 6 women out of 280 were graduates.

Table 3: Educational status.

\begin{tabular}{|lll|}
\hline Education status & No. & Percentage \\
\hline Illiterate & 8 & 3 \\
\hline Primary school & 246 & 88 \\
\hline High school & 20 & 7 \\
\hline Graduate & 6 & 2 \\
\hline
\end{tabular}

Table 4: Parity.

\begin{tabular}{|lll|}
\hline Parity & No. & Percentage \\
\hline Primipara & 106 & 38 \\
\hline Living $2-4$ & 122 & 43.5 \\
\hline Living $>4$ & 52 & 18.5 \\
\hline
\end{tabular}


Table 5: Awareness of family planning.

\begin{tabular}{|lll|}
\hline A wareness of family planning & No. & Percentage \\
\hline Yes & 246 & 88 \\
\hline No & 34 & 12 \\
\hline
\end{tabular}

Table 6: Knowledge about the contraceptive method.

\begin{tabular}{|c|lll|}
\hline \multirow{5}{*}{ Methods } & No. & Percentage \\
\hline \multirow{5}{*}{ Temporary } & CuT & 82 & 79 \\
\cline { 2 - 3 } & Barrier & 10 & 5 \\
& OCP & 22 & 11 \\
\cline { 2 - 4 } & Safe period & 4 & 2 \\
\cline { 2 - 4 } & $\begin{array}{l}\text { Lactational } \\
\text { amenorrhea }\end{array}$ & 4 & 2 \\
\cline { 2 - 4 } & Injectables & 2 & 1 \\
\hline \multirow{3}{*}{ Permanent } & $\begin{array}{l}\text { Emergency } \\
\text { contraception }\end{array}$ & 0 & 0 \\
\cline { 2 - 4 } & Norplant & 0 & 0 \\
\hline & Male & 0 & 0 \\
\hline & Female & 76 & 26 \\
\hline
\end{tabular}

Majority of the women had 2 or 3 living children and only 53 women out of 280 were primiparas.

About $79 \%$ of the patients were aware of $\mathrm{CuT}$ and $11 \%$ women were aware of oral contraceptives. However only $5 \%$ women were aware of the safe period, lactational amenorrhea and injectables. It was disappointing to note that none of the patients were aware of emergency contraception, norplant and not surprisingly the male contraception.

Table 7: Attitude of the women towards contraception.

\begin{tabular}{|lll|}
\hline Willing & No. & Percentage \\
\hline Yes & 104 & 37.1 \\
\hline No & 176 & 58.6 \\
\hline
\end{tabular}

Most of the womens' attitude towards the use of family planning method was not satisfactory. Most of them said that they act according to their spouse's or their in law's decision. They have no choice related to child birth.

Table 8: Reasons for willingness of contraception.

\begin{tabular}{|lll|}
\hline Reasons for willingness & No. & Percentage \\
\hline Completed family & 80 & 78 \\
\hline Financial crises & 16 & 16 \\
\hline Spacing & 8 & 6 \\
\hline
\end{tabular}

It was disappointing to not that out of the 280 women only 104 women were willing for sterilization. However, out of 104 women who were willing for contraception, 80 women were willing for permanent sterilization (done by the Modified Pomeroy's method) and the majority were grand multies. The rest 26 women were willing for copper $\mathrm{T}$ insertion. Another disappointing fact was that only 6 primipara was willing for copper $\mathrm{T}$ instertion. Moreover, the other temporary methods like progesterone only pills, injectables or norplant devices were not opted.

Table 9: Reason for unwillingness of contraception.

\begin{tabular}{|lll|}
\hline Reasons for unwillingness & No. & Percentage \\
\hline Lack of knowledge & 96 & 34 \\
\hline Side effects & 22 & 8 \\
\hline More children & 30 & 11 \\
\hline Husband not willing & 34 & 12 \\
\hline Sex of the baby & 48 & 17 \\
\hline Religion & 22 & 8 \\
\hline Fear of health problems & 28 & 10 \\
\hline
\end{tabular}

Table 10: Practice of contraception.

\begin{tabular}{|lll|}
\hline Methods & No. & Percentage \\
\hline Temporary & 26 & 25 \\
\hline Permanent & 78 & 75 \\
\hline
\end{tabular}

\section{DISCUSSION}

Around $88 \%$ of the women knew that there are methods to prevent pregnancy whereas the rest were unaware of the idea of contraception, majority of the women being primiparas of age 20 years and below. Among 246 women who were aware about the contraception, majority of the women knew about the contraceptive methods (both permanent and temporary) through media (mainly television and radio). Social circles also helped women to gain knowledge about contraception, mainly from their mothers or elder sisters. The least number was informed by health personnel.

In the study that lasted for 2 months, $37.1 \%$ were willing for contraception (either permanent or temporary) whereas the rest of the women were not willing for contraception. Among the 104 women, only 26 women opted for temporary methods, the most common being the copper T. Among the $37.1 \%$ of women who were willing for contraception, 40 women had completed their family whereas $16 \%$ of the women stated that it was due to financial crisis that they opted for contraception. The rest of the women utilized contraception for spacing. However, among 58.6\% women were not willing for contraception, 48 women were not aware of contraception. Another $17 \%$ women were not willing as they were not happy with the sex of the baby (most of the women and their families preferred male babies). It was also noted that none of the postnatal women had enquired about the other methods of contraception which clearly indicated their lack of interest/knowledge of contraception.

In their study among rural Rajputs, they found that the raise in education besides providing knowledge and the contraceptive methods helps in improving acceptance of family control devices. There are also other studies carried out in this sphere., ${ }^{4,9}$ According to NFHS-3, 
about $30 \%$ of the fertility in India was unwanted, indicating a huge gap between the demand and supply of family planning and the unmet need of the country as a whole is about $13 \%$ and this is high among married women aged 15-19 years (25\% for spacing and $2 \%$ for limiting) and among those aged 20-24 years (15\% for spacing and over $6 \%$ for limiting). ${ }^{10,11}$ But in spite of availability of sterilization facilities and contraceptive measures free of cost by the Government of India, couples refuse to adopt them. ${ }^{12}$ The reasons for this refusal have to be analyzed to the core, for a better understanding of the situation and to help the Government formulate appropriate policies and modified approaches, thereby helping change the social outlook of contraception and promote an increased usage of the same. ${ }^{13,14}$

\section{CONCLUSION}

Practicing family planning and to choose the correct contraceptives is very much essential. We recommend sustained efforts to increase awareness and motivation for contraceptive use by the health care personnel.

\section{Recommendation}

Education and communication with the reproductive age couples, and improved social and welfare services can be given. These couples should be given information about contraceptives at every visit to the health services to motivate them. Motivation of the males towards the usage of male contraceptive measures (both temporary and permanent) is very much necessary. The most important factor is regular availability of contraceptives and adequate health care services at the peripheral level. The education levels also need to be raised among the children as it can improve their knowledge about the contraception and moreover they can realise the need of contraception and can also have a quality life.

Funding: No funding sources Conflict of interest: None declared

Ethical approval: The study was approved by the Institutional Ethics Committee

\section{REFERENCES}

1. Park K. Park's Textbook of Preventive and Social Medicine. 20 ${ }^{\text {th }}$ Edition; 2009:421.

2. Dabral S, Malik SL. Demographic Study of Gujjars of Delhi: IV. KAP of Family Planning. J Hum Ecol. 2004;16(4):231-7.
3. Gautam AC, Seth PK. Appraisal of the knowledge, attitude and practices (KAP) of family control devises among rural Rajputs and scheduled caste of Hatwar area of Bilaspur district, Himachal Pradesh. Anthropologist. 2001;4(4):289-92.

4. Takkar N, Goel P, Saha PK, Dua D. Contraceptive practices and awareness of emergency contraception in educated working women. Indian $\mathrm{J}$ Med Sci. 2005;59:143-9.

5. Speroff L, Darney PD. A clinical guide for contraception. 5th edition. Lippincott Williams \& Wilkins. Philadelphia;2011.

6. Srinivasan K, Jejeebhoy SJ, Easterlin RA. Factors affecting fertility control in India: a cross sectional study. Popul Dev Rev. 1984;10;273-95.

7. USAID. Key Indicators for Urban Poor in Madhya Pradesh from NFHS-3 and NFHS-2. Available from http://uhrc.in/downloads/Factsheet-India.pdf (assessed on Jan 2011).

8. Reddy SR, Premarajan KC, Narayan KA, Mishra AK. Rapid appraisal of knowledge, attitude and practices related to family planning methods among men within 5 years of married life. Indian J Prev Soc Med. 2003;34:63-6.

9. Sunita TH, Desai RM. Knowledge, attitude and practice of contraception among women attending a tertiary care hospital in India. Int $\mathrm{J}$ Reprod Contracept Obstet Gynecol, 2013;2(2):172-6.

10. National family health survey-3(NFHS-3), 2005-06, volume-1, international institute for population sciences, Deonar, Mumbai, Ministry of Health And Family Welfare, GOI.

11. Bhasin K, Pant M, Mehta M, Kumar S. Prevalence of usage of different contraceptive methods in East Delhi- a cross sectional study. Indian J Comm Med. 2005;30:52-5.

12. Kaushal SK, Saxena SC, Srivastava VK, Gupta SC, Nigam S. KAP study on contraceptive methods in Kanpur district of UP. Indian J Comm Health. 2010;21:33-8.

13. Dabral S, Malik SL. Demographic study of Gujjars of Delhi: IV. KAP of family planning. J Hum Ecol. 2004;16(4):231-7.

14. Renjhen P, Gupta SD, Barua A, Jaju S, Khati B. A study of knowledge, attitude and practice among women of reproductive age group in Sikkim. J Obstet Gynaecol India. 2008;58:63-7.

Cite this article as: Kripa S, Shetty H. Knowledge, attitude and practice of contraception among the postnatal women in a tertiary care hospital in a rural area in Southern Karnataka, India. Int J Reprod Contracept Obstet Gynecol 2017;6:1821-4. 